Bangladesh J. Bot. 44(2): 261-265, 2015 (June)

\title{
ONOSMA DEMIRIZII (BORAGINACEAE), A NEW SPECIES FROM CENTRAL ANATOLIA, TURKEY
}

\author{
Gül TaRimcilar*, Özer Yilmaz AND GönüL KaYNAK \\ Uludağ University, Faculty of Arts and Sciences, Department of Biology, \\ TR-16059, Görükle Campus, Nilüfer / Bursa, Turkey.
}

Key words: Boraginaceae, New species, Onosma, Turkey

\begin{abstract}
Onosma demirizii Kaynak, Tarımcilar \& Y1lmaz sp. nova (Boraginaceae) is described as a new species from central Anatolia, Turkey. This new species is closely related to $O$. subulifolium $\mathrm{H}$. Riedl but differs by its yellowish-green stems, patent-setose indumentum, linear to narrowly oblanceolate cauline leaves, shorther calyx and corolla and anthers that are longer than the filaments. The diagnostic morphological characters of this new species are discussed.
\end{abstract}

\section{Introduction}

The Boraginaceae family is distributed mainly in temperate, pantropical and subtropical areas and comprises approximately 150 genera and 2700 species worldwide (Heywood et al. 2007). The genus Onosma L. is restricted to Asia and Europe and includes about 150 species (Peruzzi and Passalacqua 2008). Onosma is a systematically difficult genus, and most of the diagnostic characters are based mainly on the whole indumentums, leaf and flower morphology (Ball 1972, Riedl 1978, Pavlova 2009). Riedl (1978) has reported 88 species of Turkish flora. Currently, 10 new species have been recognised by different authors (Davis et al. 1988 Güner 2000, Yildırımlı 2000, Riedl et al. 2005, Binzet and Orcan 2007, Kandemir and Türkmen 2010, Aytaç and Türkmen 2011, Koyuncu et al. 2013). Approximately half of the species are endemic to the Flora of Turkey. In this paper, a new species of the genus Onosma is described.

\section{Materials and Methods}

Flowering specimens were collected during a botanical survey in central Anatolia around Kayseri province in the spring of 2013. These specimens were compared to Onosma species that were kept at ANK, BULU and digital images from $\mathrm{E}$ and different herbaria were studied. In addition, these specimens were checked against the literature cited above. For the scanning electron microscope studies, stem leaves were coated with gold-palladium for $4 \mathrm{~min}$ in a BALTEC SCD 005 sputter-coater (Leica Microsystems, Wetzlar, Germany). All of the observations were made on a Carl Zeiss EVO 40 (Carl Zeiss AG, Oberkochen, Germany) at a voltage of $15 \mathrm{kV}$.

\section{Results and Discussion}

Onosma demirizii Kaynak, Tarımclar \& Yılmaz sp. nova

(Figs 1, 2, 3)

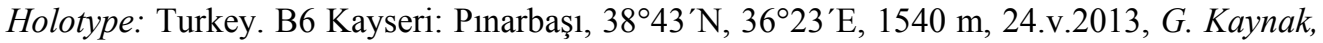
Ö. Yllmaz s.n. (BULU 35011).

Diagnosis: This new species is closely related to Onosma subulifolium $\mathrm{H}$. Riedl. However $O$. demirizii is different by its yellowish-green stem with patent-setose indumentums; linear to narrowly oblanceolate, and $12-16 \mathrm{~mm}$ long (not $15-32 \mathrm{~mm}$ ) cauline leaves; setose and $7-9 \mathrm{~mm}$ long (not hispid, $10-11 \mathrm{~mm}$ ) calyx; cream coloured and $12-14 \mathrm{~mm}$ long (not $15-18 \mathrm{~mm}$ ) corolla, and anthers that are longer than the filaments.

*Author for correspondence: < gult@uludag.edu.tr> Department of Biology, Faculty of Arts and Sciences, Uludağ University, TR-16059, Görükle Campus, Nilüfer / Bursa, Turkey. 
Table 1. Comparison of some morphological characteristics Onosma demirizii, $O$. subulifolium and O. thracicum.

\begin{tabular}{|c|c|c|c|}
\hline & O. demirizii & O. subulifolium & O. thracicum \\
\hline Stem & $11-17 \mathrm{~cm}$ & $6-12 \mathrm{~cm}$ & $12-25 \mathrm{~cm}$ \\
\hline Indumentum & Yellowish-green patent-setose & Bluish black adpressed-setose & Green patent-setose \\
\hline Leaves & $\begin{array}{l}12-16 \times 1-2 \mathrm{~mm} \text { linear to } \\
\text { narrowly oblanceolate }\end{array}$ & $15-32 \times 1-1.8 \mathrm{~mm}$ subulate & $\begin{array}{l}10-29 \times 1-5 \mathrm{~mm} \\
\text { linear-oblong }\end{array}$ \\
\hline Bracts & 6 - $9 \mathrm{~mm}$ revolute & 7 - $8 \mathrm{~mm}$ flat & - \\
\hline Calyx & 7 - $9 \mathrm{~mm}$ setose & $10-11 \mathrm{~mm}$ hispid & $6-8 \mathrm{~mm}$ setose \\
\hline Corolla & 12 - $14 \mathrm{~mm}$ cream, glabrous & $15-18 \mathrm{~mm}$ white, glabrous & $\begin{array}{l}11-19 \mathrm{~mm} \text { pale yellow } \\
\text { puberulent }\end{array}$ \\
\hline Filament & $\begin{array}{l}\text { Anthers are longer than } \\
\text { the filaments }\end{array}$ & $\begin{array}{l}\text { Filaments are } \\
\text { equal to anthers }\end{array}$ & - \\
\hline Inflorescence & Short cyme, subcapitate & Subcapitate cyme & Lax cyme \\
\hline
\end{tabular}

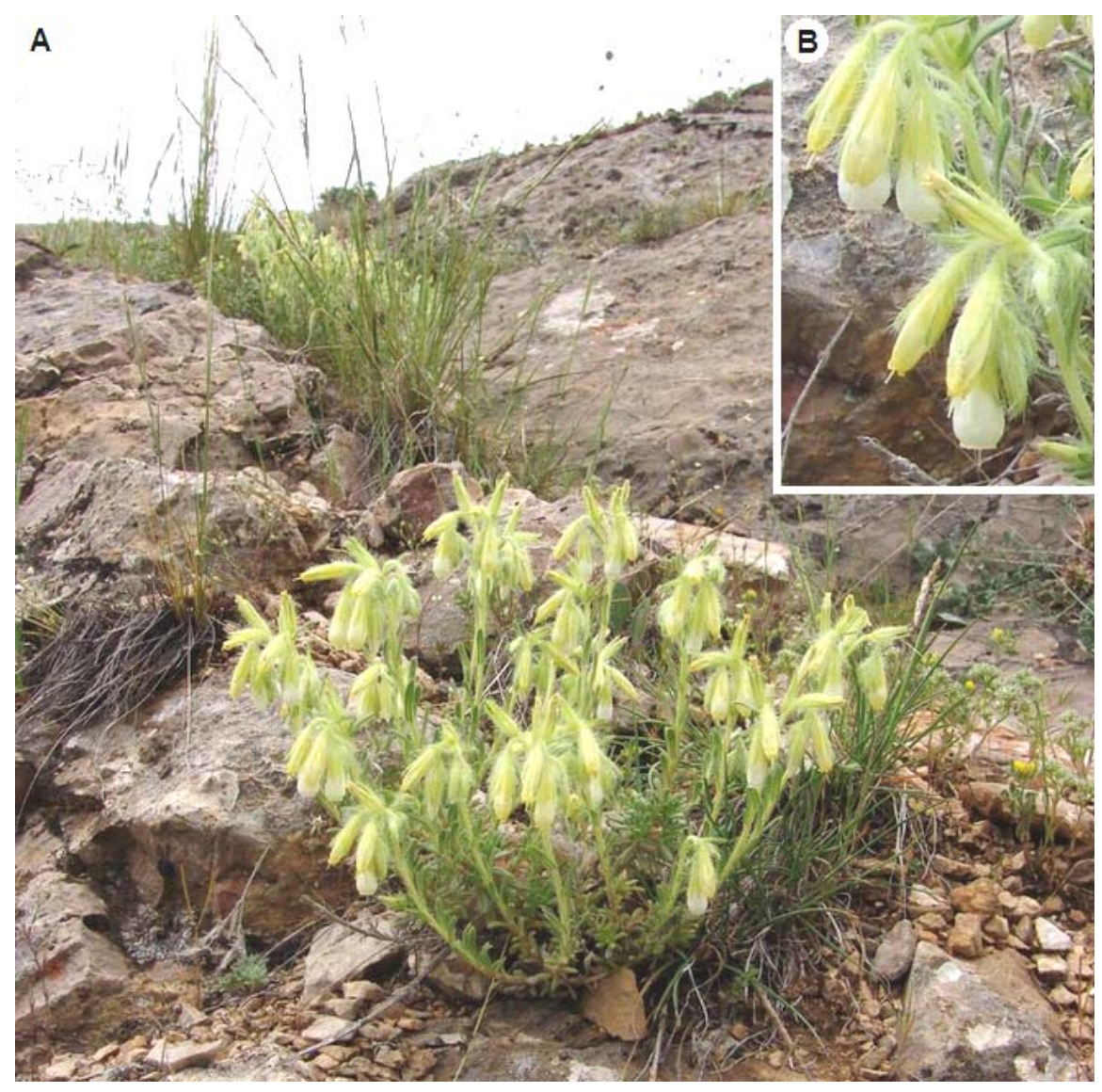

Fig. 1. Onosma demirizii in the wild. A- Habit. B- Flowers (photos Gönül Kaynak). 


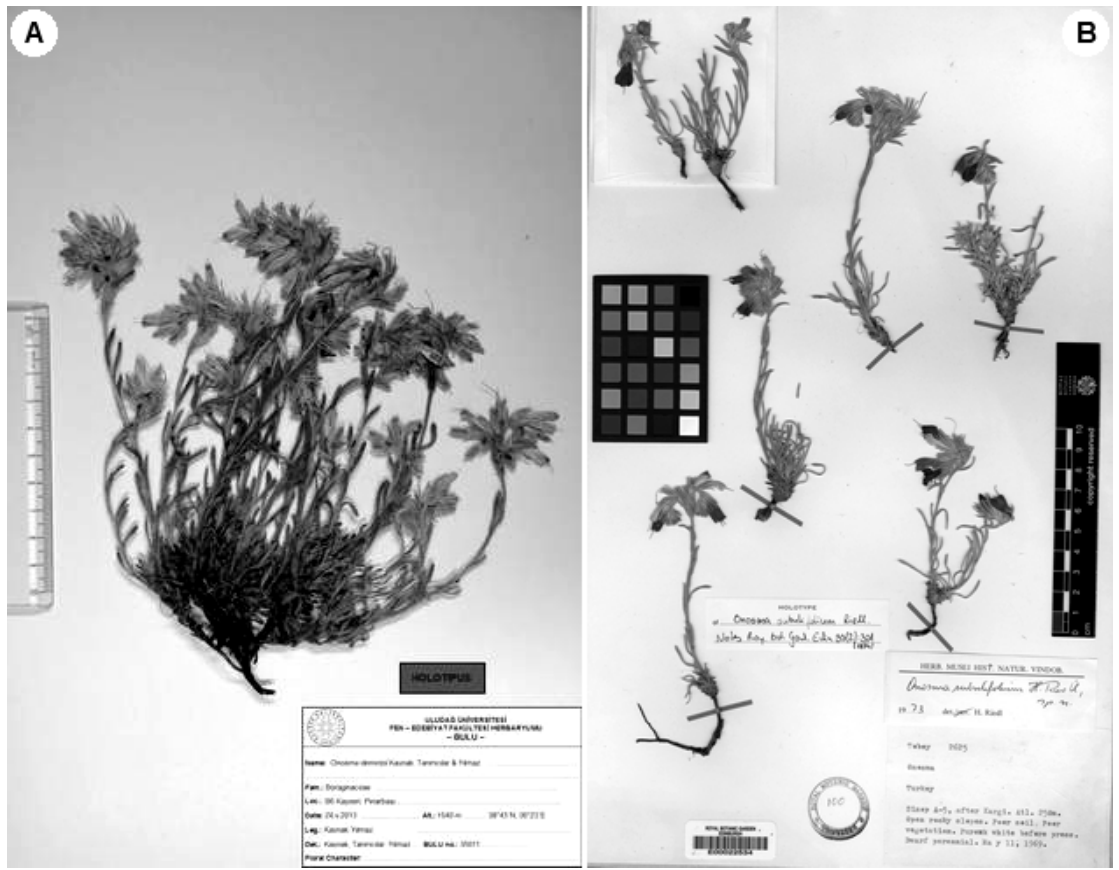

Fig. 2. A- Holotype of $O$. demirizii from the herbarium BULU (photo Özer Y1lmaz). B- Type of $O$. subulifolium from the herbarium E. (available at website:http://elmer.rbge.org.uk/bgbase/vherb/bgbasevherb.php?cfg = bgbase/ vherb/zoom. cfg\&filename $=$ E00022534.zip\&queryRow $=1$ ).
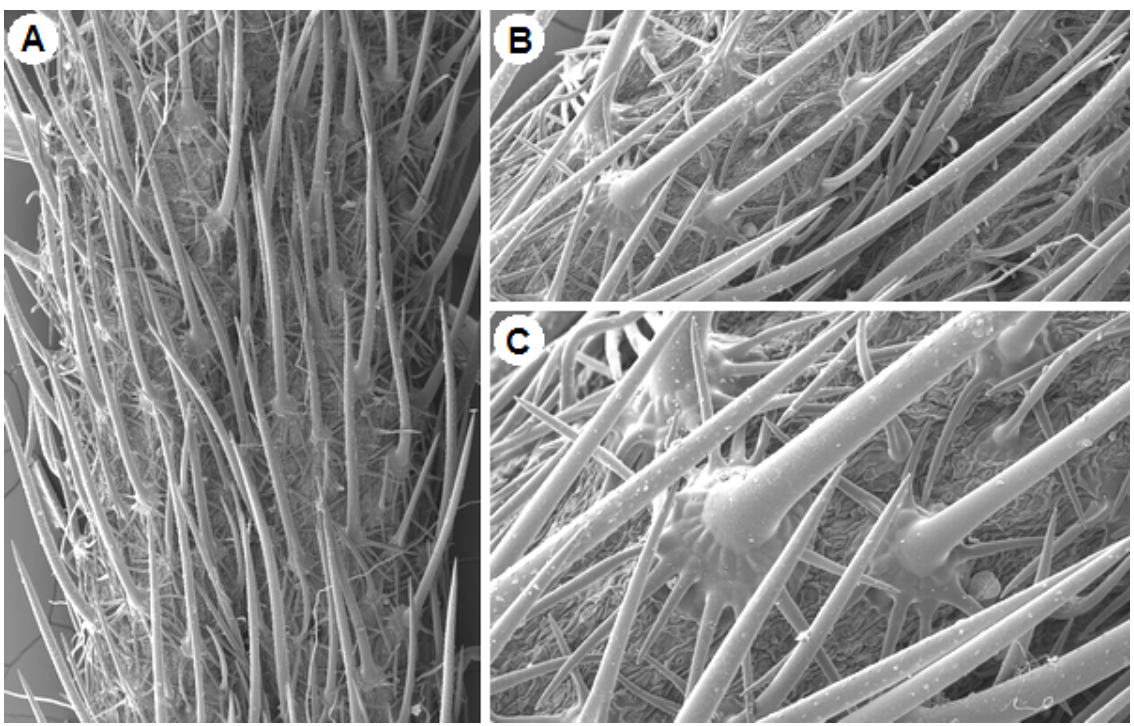

Fig. 3. A- Leaf indumentum of Onosma demirizii $(\times 100)$. B- Asterotrichous hair in general view $(\times 150)$. C- Asterotrichous hair in closer view $(\times 300)$. 


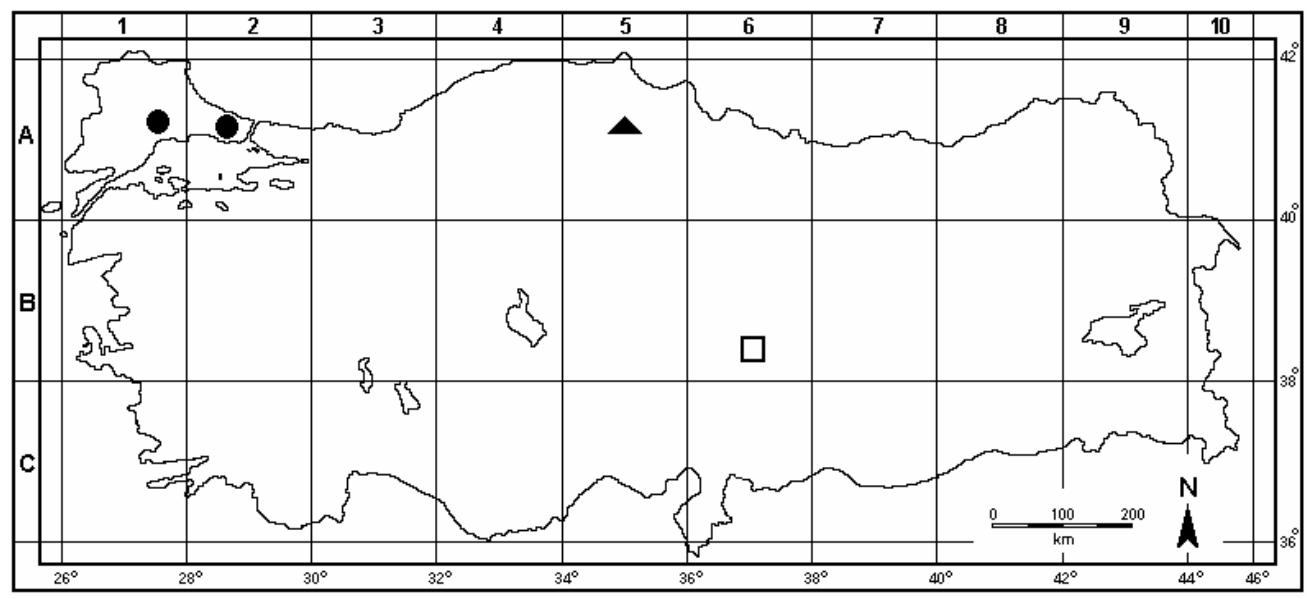

Fig. 4. Map shows the distribution of Onosma demirizii ( $\square)$, O. subulifolium (A) and $O$. thracicum $(\bullet)$ in Turkey.

Description: Perennial. Stem numerous, $11-17 \mathrm{~cm}$, erect to ascending yellowish-green with long patent stellate tubercles and whitish setose hairs. Basal leaves crowded in to an irregular tuft or rosette, shorter than cauline leaves spathulate, margins strongly revolute, shorter than cauline leaves, $6-12 \times 0.6-1.2 \mathrm{~mm}$ wide, upper surface dull greyish-green, densely long patent stellate tubercles robust setae, $1.5-2 \mathrm{~mm}$ long, lower surface with adpressed short setae, $2-3.5 \mathrm{~mm}$ long, indumentum \pm uniform on both surface. Cauline leaves linear to narrowly oblanceolate, $12-16 \times$ $1-2 \mathrm{~mm}$, margins strongly revolute, densely clothed with yellowish-green long patent stellate tubercles, robust setae on the upper surface, $2-3.5 \mathrm{~mm}$ long; lower surface with adpressed short setae, 1.5 - $3 \mathrm{~mm}$ long. Inflorescence cyme, short subcapitate. Bracts $6-9 \times 1-2 \mathrm{~mm}$, foliaceous, linear-lanceolate, revolute, acute, setose with similar indumentum as the stem and leaves. Pedicels $1-1.5 \mathrm{~mm}$ long, setose. Calyx divided almost to base lobes, lobes narrowly linear, 7 - $9 \mathrm{~mm}$ long, densely covered with long adpressed setae, a few long patent setae and short thin hairs on the upper surface. Corolla 12 - $14 \mathrm{~mm}$ long, clavate-campanulate, lobes short acute, glabrous, creamcoloured, pale yellow when dry. Anthers included, linear, $5-5.5 \times 1 \mathrm{~mm}$ wide; apex acuminate membranous, base sagittate; free part of filament $5-5.5 \mathrm{~mm}$ long, coherent only near apex, flattened, glabrous. Ovary glabrous, approximately $1 \mathrm{~mm}$ diam. Style filiform, exserted, approximately $16 \mathrm{~mm}$, longer than corolla. Stigma distinctly 2-lobed. Nutlets unknown.

Distribution and habitat: This new species is endemic to central Anatolia. Onosma demirizii is only known from the type locality and is geographically well isolated from the related species (Fig. 4). This new species grows on calcareous rocky slopes with Onosma albo-roseum Fisch., Scrophularia libanotica Boiss., Aubrieta canascens (Boiss.) Bornm subsp. canescens, Asphodeline taurica (Pallas) Kunt and Ebenus laguroides Boiss.var. laguroides at an altitude of greater than $1500 \mathrm{~m}$.

Phenology: Flowering in May.

Etymology: This species is named in honour of the eminent Turkish Botanist, Professor Dr. Hüsnü Demiriz (1920 - 1999) (Department of Biology, Istanbul University).

Conservation status: Onosma demirizii is endemic to Turkey. It is known from the type locality only. It is known from one locality (criterion B2 a), with an estimated area of less than 10 $\mathrm{km}^{2}$ (criterion B2). The population is unhealty with less than 100 indivudials (criterion C). 
Therefore it should be classified as "Critically Endangered (CR)" based on the criteria of the IUCN Red List Categories (IUCN, 2001).

Onosma demirizii is closely related to O. subulifolium; however, this new species is considerably different. $O$. demirizii has yellowish-green patent-setose indumentum, linear to narrowly oblanceolate cauline leaves, shorter calyx and corolla, anthers that are longer than the filaments.

Additionally, this new species has similarities with $O$. thracicum Velen., but differs by its shorter stem, revolute leaves, glabrous and cream corolla, and subcapitate inflorescence (Table 1). Onosma demirizii and the remaining two have asterotrichous indumentum (Fig. 3). According to the Flora of Turkey (Riedl 1978) they belong to the subsect. Asterotricha (Boiss.) Gürke.

\section{Acknowledgements}

The authors wish to thank the authorities of Research Foundation of Uludağ University for financial support (Project no: KUAP (F)-2013/83).

\section{References}

Aytaç Z and Türkmen Z 2011. A new Onosma (Boraginaceae) species from southern Anatolia, Turkey. Turk. J. Bot. 35: 269-274.

Ball PW 1972. Onosma L In: Flora Europaea (T.G. Tutin, V.H. Heywood Eds.), vol. 3. pp. 89-94. Cambridge University Press, Cambridge Binzet R and Orcan N 2007. A new species of Onosma L. (Boraginaceae) From Southern Turkey. Novon 17(1): 8-10.

Binzet R and Orcan N 2007. A new species of Onosma L. (Boraginaceae) From Southern Turkey. Novon 17(1): 8-10.

Davis PH, Mill RR and Tan K 1988. Onosma L. In: Flora of Turkey and the East Aegean Islands (Davis PH, Mill RR and Tan K Eds.), (Suppl. 1), vol. 10. pp. 184-185. Edinburgh University Press, Edinburgh.

Güner A 2000. Onosma L. In: Flora of Turkey and the East Aegean Islands (Güner A, Özhatay N, Ekim T and Başer KHC Eds). (Suppl. 1), vol. 11. p. 188. Edinburgh University Press, Edinburgh.

Heywood VH, Brummitt R, Culham A and Seberg O 2007. Flowering Plant Families of the World. Royal Botanic Gardens Kew, Kew Press. London. pp. 424.

IUCN. 2001. IUCN Red List Categories and Criteria: version 3.1. IUCN Species Survival Commission. IUCN, Gland, Switzerland, Cambridge.

Kandemir A and Türkmen Z 2010. A new species of Onosma (Boraginaceae) from eastern Turkey. Turk. J. Bot. 34: 277-282.

Koyuncu O, Yaylacı OK, Özgişi K, Sezer O and Öztürk D 2013. A new Onosma (Boraginaceae) species from Central Anatolia, Turkey. Plant. Syst. Evol. 299:1839-1847.

Peruzzi L and Passalacqua NG 2008. Taxonomy of the Onosma echioides (L.) L. complex (Boraginaceae) based on morphometric analysis. Bot. J. Linn. Soc. 157: 763-774.

Pavlova D 2009. Onosma bulgarica sp. nov. (Boraginaceae- Lithospermeae) found on serpentine in Bulgaria. Nordic J. Bot. 27: 216-221.

Riedl H 1978. Onosma L. In: Flora of Turkey and the East Aegean Islands (P.H. Davis Eds.) vol. 6. pp. 326376. Edinburgh University Press, Edinburgh, UK.

Riedl H, Binzet R and Orcan N 2005. A new species of Onosma (Boraginaceae-Lithospermae) from southern Turkey. Edinburgh J. Bot. 61: 127-130.

Yildırıml S 2000. The chorology of the Turkish species of Boraginaceae family. Ot Sistematik Botanik Dergisi 7: 257-272. 